\title{
One-pot preparation of substituted pyrroles from a-diazocarbonyl compounds
}

\author{
Fernando de C. da Silva, Mauricio G. Fonseca, Renata de S. Rianelli, \\ Anna C. Cunha, Maria C. B. V. de Souza and Vitor F. Ferreira*
}

\section{Full Research Paper}

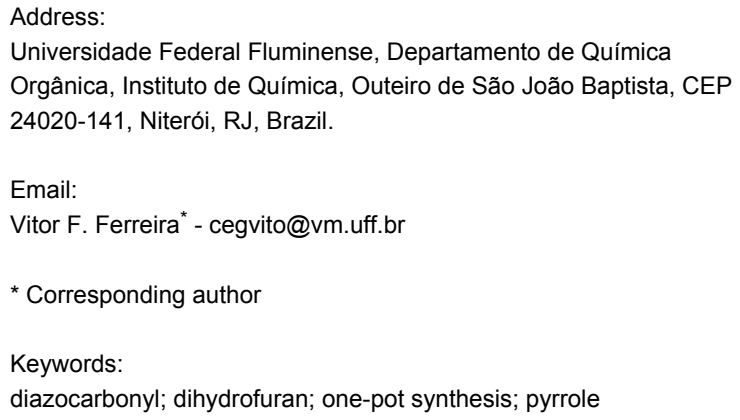

Beilstein Journal of Organic Chemistry 2008, 4, No. 45 doi:10.3762/bjoc. 4.45

Received: 31 October 2008

Accepted: 18 November 2008

Published: 28 November 2008

(C) 2008 da Silva et al; licensee Beilstein-Institut.

License and terms: see end of document.

\begin{abstract}
In this work an efficient one-pot synthesis of substituted pyrroles $\mathbf{7 a}-\mathbf{n}$ is described, which involves the in situ formation of dihydrofurans ethyl 5-butoxy-2-methyl-4,5-dihydrofuran-3-carboxylate (4), 1-(5-butoxy-2-methyl-4,5-dihydrofuran-3-yl)ethanone (5) and 5-butoxy-4,5-dihydrofuran-3-carbaldehyde (6) followed by reaction with primary amines.
\end{abstract}

\section{Introduction}

The pyrrole unit [1] occurs in many interesting classes of compounds such as pharmaceutical agents [2-5], conducting polymers [6,7], molecular optics [8-11], electronics [12], gas sensors for organic compounds [13], and as building blocks in many physiologically interesting natural products, such as alkaloids [14]. The classical methods of constructing pyrrole ring system include mainly Knorr or Paal-Knorr syntheses, which have been summarized in a wide number of review articles [15-19]. Due to these multiple uses and varieties of biological activities, the synthesis of this ring system has been subject of intense investigation. Danks [20] developed a high yield Paal-Knorr method of synthesis of pyrroles by the reaction between hexane-2,5-dione and primary amines under microwave irradiation. Other processes including several claymediated synthetic variations of these classical methods also have been reported for preparing pyrroles in equal or better yields [21]. In 2001 [22] and 2004 [23], Banik and co-workers, by using the same protocol developed by Danks, reported the synthesis of pyrroles using montmorillonite KSF in a solventfree process accelerated by microwave irradiation. More recently, Yadav and co-workers [24] described an efficient protocol for the synthesis of sugar derived optically active di-pyrrolyl and bis-indolyl alkanols that are important for the synthesis of porphyrins, using montmorillonite KSF as catalyst. The search for short procedures for the synthesis of highly functionalized pyrrole derivatives is still desirable [25-27].

In the next years the organic synthetic chemists will have more demanding tasks, which include the search of products that can be manufactured in environmentally acceptable ways with 
minimum consumption of energy and abundant raw materials (e.g. biomass). The new reactions must maintain a favorable ecological balance to be acceptable by society. In many books, the definition of the ideal synthesis agrees with several demanding tasks mentioned before in such way that the target molecules should be made from readily available starting materials in one simple, safe, environmentally acceptable operation. Additionally, they also should proceed quickly, in quantitative yield, with high atom economy, and be more convergent than one or two-component reactions.

$\alpha$-Diazocarbonyl compounds have a long history of useful applications in organic chemistry. They are easily prepared from readily accessible precursors and can be used in a wide variety of chemical transformations [28]. Indeed, we prepared several pyrroles from diazocarbonyl compounds in two steps [29] employing dihydrofurans. However, these latter compounds were difficult to prepare, isolate and transform into the pyrroles [30]. In this manuscript, we report the preparation of pyrroles from diazodicarbonyl compounds in a one-pot reaction.

\section{Results and Discussion}

The substituted pyrroles $7 \mathbf{a}-\mathbf{n}$ were prepared according to the synthetic pathways described in Scheme 1. $\alpha$-Diazocarbonyl compounds ethyl 2-diazoacetoacetate (1), 3-diazopentane-2,4dione (2) and diazomalonaldehyde (3) were treated with a catalytic quantity of rhodium(II) acetate in the presence of butyl vinyl ether to produce the corresponding 3-carbonyl-dihydrofurans 4-6. The rhodium catalyzed reaction of the $\alpha$-diazocarbonyl compounds 1-3 was monitored by TLC chromatography. Evaporation of the solvents at the end of these reactions followed by purification of crude residues by column chromatography led to the pyrroles $\mathbf{7 a}-\mathbf{n}$ in moderate to good yields. Their structures were confirmed mainly based on their ${ }^{13} \mathrm{C}$ and ${ }^{1} \mathrm{H}$ NMR spectral data which are depicted in the experimental section.

Since the reactivities of the diazo compounds are different there were variations in the reaction times (see Table 1). The reaction of the dihydrofuran intermediates 4,5 and $\mathbf{6}$ with excess of primary amines in the presence of glacial acetic acid afforded the corresponding substituted pyrroles $7 \mathbf{a}-\mathbf{n}$ in moderate to good yields (Table 1). Slightly different reactivity between 4, 5

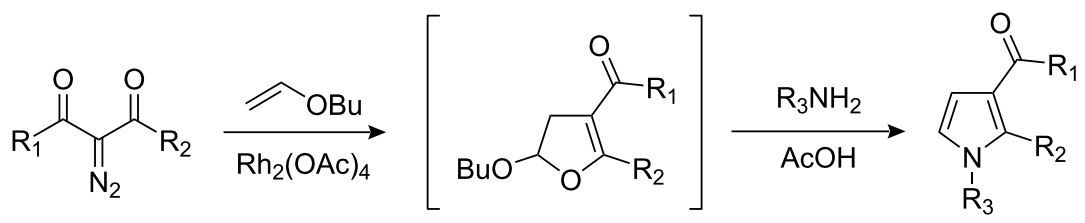

1, $\mathrm{R}_{1}=\mathrm{OEt}, \mathrm{R}_{2}=\mathrm{CH}_{3}$

4, $\mathrm{R}_{1}=\mathrm{OEt}, \mathrm{R}_{2}=\mathrm{CH}_{3}$

$7 a-n$

2, $\mathrm{R}_{1}=\mathrm{R}_{2}=\mathrm{CH}_{3}$

5, $\mathrm{R}_{1}=\mathrm{R}_{2}=\mathrm{CH}_{3}$

$3, R_{1}=R_{2}=H$

6, $R_{1}=R_{2}=H$

Scheme 1: One-pot synthesis of pyrrole derivatives.

\begin{tabular}{|c|c|c|c|c|c|c|}
\hline Entry & $7 a-n$ & $\mathrm{R}_{1}$ & $\mathrm{R}_{2}$ & $\mathrm{R}_{3}$ & $t(h)$ & Yield (\%) \\
\hline 1 & $7 a$ & OEt & $\mathrm{Me}$ & Benzyl [29] & 52 & 72 \\
\hline 2 & $7 b$ & OEt & $\mathrm{Me}$ & Decyl [29] & 60 & 79 \\
\hline 3 & 7c & OEt & $\mathrm{Me}$ & Cyclohexyl [29] & 72 & 74 \\
\hline 4 & $7 d$ & OEt & $\mathrm{Me}$ & Isopropyl [31] & 76 & 21 \\
\hline 5 & $7 e$ & OEt & $\mathrm{Me}$ & Butyl & 48 & 69 \\
\hline 6 & $7 f$ & $\mathrm{Me}$ & $\mathrm{Me}$ & Decyl [29] & 44 & 66 \\
\hline 7 & $7 g$ & $\mathrm{Me}$ & $\mathrm{Me}$ & Benzyl [29] & 61 & 73 \\
\hline 8 & $7 \mathrm{~h}$ & $\mathrm{Me}$ & $\mathrm{Me}$ & Cyclohexyl [29] & 56 & 64 \\
\hline 9 & $7 i$ & $\mathrm{Me}$ & $\mathrm{Me}$ & Isopropyl & 54 & 23 \\
\hline 10 & $7 \mathbf{j}$ & $\mathrm{Me}$ & $\mathrm{Me}$ & Butyl [29] & 51 & 62 \\
\hline 11 & $7 k$ & $\mathrm{H}$ & $\mathrm{H}$ & Benzyl [30] & 48 & 86 \\
\hline 12 & 71 & $\mathrm{H}$ & $\mathrm{H}$ & Butyl [32] & 48 & 83 \\
\hline 13 & $7 m$ & $\mathrm{H}$ & $\mathrm{H}$ & Propyl [33] & 48 & 85 \\
\hline 14 & $7 n$ & $\mathrm{H}$ & $\mathrm{H}$ & $\mathrm{H}[34]$ & 24 & 65 \\
\hline
\end{tabular}


and 6 was observed since the former reaction involves a nucleophilic attack to vinylogous carbonyls of 3-carbonyl-dihydrofurans.

In general, the yields were dependent basically on the reactivity of the diazocompounds. In fact, diazocompound $\mathbf{3}$ led to higher yields and lower reaction times than 1 or 2 (entries 11-14). Most of the amines had little influence on the reaction yields, with the exception of isopropylamine that led to the pyrroles in lower yields (entries 4 and 9), probably due to steric hindrance of the methyl groups. In some experiments the products were obtained in a high degree of purity (entries 11 and 14). Additionally, pyrrole $7 \mathbf{k}$, in our previous work [30], was obtained in $16 \%$ yield and by using this methodology was obtained in higher yield ( $86 \%$, entry 11$)$.

\section{Conclusion}

In summary, this one-pot methodology for the synthesis of substituted pyrroles from $\alpha$-diazocarbonyl compounds is a very straightforward route to construct variously substituted compounds of this class starting from readily available precursors.

\section{Experimental}

Analytical grade solvents were used. Butyl vinyl ether was freshly distilled before being used. Column chromatography was performed on silica gel 60 (Merck 70-230 mesh). Infrared spectra were recorded on a Perkin-Elmer 1420 spectrophotometer. NMR spectra were recorded with a Varian Unity Plus 300 spectrometer, operating at $300 \mathrm{MHz}\left({ }^{1} \mathrm{H}\right)$ and $75 \mathrm{MHz}$ $\left({ }^{13} \mathrm{C}\right)$, with tetramethylsilane as the internal standard. Ethyl 2-diazoacetoacetate (1) [35], 3-diazopentane-2,4-dione (2) [36], and diazomalonaldehyde (3) [37] were prepared following the procedures described in the literature. Purified samples were used for measuring physical constants and spectral data. Highresolution mode TOF-ESIMS mass spectra were obtained with Hewlett Packard 5985 instrument.

\section{General procedure}

A solution of the diazodicarbonyl compound (1-3, 2 mmol) in 5 $\mathrm{mL}$ of freshly distilled butyl vinyl ether was slowly added by a syringe pump, at a rate of $1.0 \mathrm{~mL} / \mathrm{h}$, to a stirred suspension of dirhodium tetraacetate $(0.2 \mathrm{mmol})$ in $5.0 \mathrm{~mL}$ of the same butyl vinyl ether as solvent, under a nitrogen atmosphere. The stirring was continued until the disappearance of the diazodicarbonyl compound followed by the addition of the appropriate amine $(4 \mathrm{mmol})$ and of $0.2 \mathrm{~mL}$ of glacial acetic acid. The mixture was stirred for the total time described in the Table 1. The solvent was removed under reduced pressure leading to a residue, which was purified by chromatography column on silica gel, using a gradient mixture of hexane/chloroform or chloroform/acetone as the eluent. For the compound $7 \mathbf{n}$ (entry 14), the butyl vinyl ether solution was saturated with ammonia and stirred for $24 \mathrm{~h}$.

1-Butyl-2-methyl-1H-pyrrole-3-carboxylic acid ethyl ester (7e). It was obtained as a yellow oil. IR $v_{\max } / \mathrm{cm}^{-1}: 2595,2873$, 1701, 1464; ${ }^{1} \mathrm{H}$ NMR $\left(300 \mathrm{MHz}, \mathrm{CDCl}_{3}\right) \delta 0.93(3 \mathrm{H}, \mathrm{t}, \mathrm{J}=7.2$ $\mathrm{Hz}), 1.35(3 \mathrm{H}, \mathrm{t}, \mathrm{J}=7.2 \mathrm{~Hz}), 1.45(2 \mathrm{H}$, sept, $\mathrm{J}=7.2 \mathrm{~Hz}), 1.68$ $(2 \mathrm{H}$, quint, $\mathrm{J}=7.5 \mathrm{~Hz}), 2.47(3 \mathrm{H}, \mathrm{s}), 3.84(2 \mathrm{H}, \mathrm{t}, \mathrm{J}=7.5 \mathrm{~Hz})$, $4.22(2 \mathrm{H}, \mathrm{q}, \mathrm{J}=7.2 \mathrm{~Hz}), 6.53(1 \mathrm{H}, \mathrm{d}, \mathrm{J}=3.0 \mathrm{~Hz}), 6.55(1 \mathrm{H}, \mathrm{d}, \mathrm{J}$ $=3.0 \mathrm{~Hz}) ;{ }^{13} \mathrm{C} \mathrm{NMR}\left(75 \mathrm{MHz}, \mathrm{CDCl}_{3}\right) \delta 10.5\left(\underline{\mathrm{CH}}_{3}\right), 13.7$ (C-4'), $14.1\left(\mathrm{OCH}_{2} \mathrm{CH}_{3}\right), 19.3\left(\mathrm{C}-3^{\prime}\right), 32.8\left(\mathrm{C}-2^{\prime}\right), 45.8\left(\mathrm{C}-1^{\prime}\right)$, $58.9\left(\mathrm{OCH}_{2} \mathrm{CH}_{3}\right), 109.5$ (C-4), 112.0 (C-3), 119.1 (C-5), 135.3 (C-2), $165.0(\mathrm{C}=\mathrm{O})$. HRMS calcd for $\mathrm{C}_{12} \mathrm{H}_{20} \mathrm{NO}_{2}[\mathrm{M}+\mathrm{H}]^{+}$: 210.1494 , found 210.2959 .

1-(1-Isopropyl-2-methyl-1H-pyrrol-3-yl)-ethanone (7i). It was obtained as a brown oil. IR $v_{\max } / \mathrm{cm}^{-1}: 2925,2871,1738$; ${ }^{1} \mathrm{H}$ NMR $\left(300 \mathrm{MHz}, \mathrm{CDCl}_{3}\right) \delta 1.25(3 \mathrm{H}, \mathrm{t}, \mathrm{J}=7.0 \mathrm{~Hz}), 1.27$ $(3 \mathrm{H}, \mathrm{t}, \mathrm{J}=7.0 \mathrm{~Hz}), 2.40(3 \mathrm{H}, \mathrm{s}), 2.53(3 \mathrm{H}, \mathrm{s}), 3.67-3.80(1 \mathrm{H}$, m), $6.48(1 \mathrm{H}, \mathrm{d}, \mathrm{J}=3.0 \mathrm{~Hz}), 6.53(1 \mathrm{H}, \mathrm{d}, \mathrm{J}=3.0 \mathrm{~Hz}) ;{ }^{13} \mathrm{C} \mathrm{NMR}$ $\left(75.0 \mathrm{MHz}, \mathrm{CDCl}_{3}\right) \delta 11.0\left(\underline{\mathrm{CH}}_{3} \mathrm{C}_{2}\right), 28.7\left(\underline{\mathrm{CH}}_{3} \mathrm{C}=\mathrm{O}\right), 32.4$ and 32.7 (C-2'), 46.1 (C-1'), 109.3 (C-4), 119.1 (C-5), 120.5 (C-3), $134.1(\mathrm{C}-2), 195.4(\mathrm{C}=\mathrm{O})$. HRMS calcd for $\mathrm{C}_{10} \mathrm{H}_{16} \mathrm{NO}$ $[\mathrm{M}+\mathrm{H}]^{+}:$166.1232, found 166.2433.

\section{Acknowledgments}

Fellowships granted to M.G.F. by CAPES and M.C.B.V.S. and V.F.F. by CNPq (Brazil) are gratefully acknowledged. This work was partially supported by CNPq (National Council of Research of Brazil) and FAPERJ.

\section{References}

1. Ferreira, V. F.; de Souza, M. C. B. V.; Cunha, A. C.; Pereira, L. O. R.; Ferreira, M. L. G. Org. Prep. Proced. Int. 2001, 33, 411-454.

2. Raimondi, M. V.; Cascioferro, S.; Schillaci, D.; Petruso, S. Eur. J. Med. Chem. 2006, 41, 1439-1445. doi:10.1016/j.ejmech.2006.07.009

3. Rochais, C.; Lisowski, V.; Dallemagne, P.; Rault, S. Bioorg. Med. Chem. 2006, 14, 8162-8175. doi:10.1016/j.bmc.2006.09.022

4. Bijev, A. Lett. Drug Des. Discovery 2008, 5, 15-24. doi:10.2174/157018008783406651

5. Zakharova, O. D.; Baranova, S.; Parissi, V.; Ryabinin, V. A.; Sinyakov, A. N.; Litvak, S.; Litvak, L. T.; Nevinsky, G. A. J. Pept. Res. 2005, 66 (Suppl. 1), 138-145.

6. Higgins, S. J. Chem. Soc. Rev. 1997, 26, 247-257. doi:10.1039/cs9972600247

7. Lee, C.-F.; Yang, L.-M.; Hwu, T.-Y.; Feng, A.-S.; Tseng, J.-C.; Luh, T.-Y. J. Am. Chem. Soc. 2000, 122, 4992-4993. doi:10.1021/ja0004736 And references therein.

8. Nizurski-Mann, R. E.; Cava, M. P. Heterocycles 1992, 34, 2003-2027.

9. Chou, S.-S. P.; Yeh, Y.-H. Tetrahedron Lett. 2001, 42, 1309-1311. doi:10.1016/S0040-4039(00)02232-2 
10. Batista, R. M. F.; Costa, S. P. G.; Malheiro, E. L.; Belsley, M.; Raposo, M. M. M. Tetrahedron 2007, 63, 4258-4265.

doi:10.1016/j.tet.2007.03.065

11. Raposo, M. M. M.; Sousa, A. M. R. C.; Kirsch, G.; Cardoso, P.; Belsley, M.; Gomes, E. M.; Fonseca, A. M. C. Org. Lett. 2006, 8, 3681-3684. doi:10.1021/ol061277s

12. D'Silva, C.; Walker, D. A. J. Org. Chem. 1998, 63, 6715-6718. doi:10.1021/jo971365d

13. de Lacy Costello, B. P. J.; Evans, P.; Guernion, N.; Ratcliffe, N. M.; Sivanand, P. S.; Teare, G. C. Synth. Met. 2000, 114, 181-188. doi:10.1016/S0379-6779(00)00250-2

14. Casiraghi, G.; Zanardi, F.; Rassu, G.; Pinna, L. Org. Prep. Proced. Int. 1996, 28, 641-682.

15. Ferreira, V. F.; de Souza, M. C. B. V.; Cunha, A. C.; Silva, F. C.; Rianelli, R. S.; Ferreira, S. B. Synthesis of heterocycles by using diazocarbonyl compounds. In Modern Approaches to the Synthesis of O- and N-Heterocycles; Kaufman, T. S.; Larghi, E. L., Eds.; Research Signpost: Kerala, 2007; Vol. 3, pp 1-44.

16. Ferreira, V. F.; de Souza, M. C. B. V.; Rianelli, R. S.; Silva, F. C.; Antunes, O. A. C. Recent advances in clay-catalyzed synthesis of heterocycles. In Progress in Catalysis Research; Bevy, L. P., Ed.; Nova Science Publishers, Inc.: New York, 2005; pp 147-175.

17. Gilchrist, T. L. J. Chem. Soc., Perkin Trans. 1 1998, 615-628. doi:10.1039/a704493c

18. Gilchrist, T. L. J. Chem. Soc., Perkin Trans. 1 1999, 2849-2866. doi:10.1039/a808162j

19. Collins, I. J. Chem. Soc., Perkin Trans. 1 2000, 2845-2861. doi:10.1039/a904715h

20. Danks, T. N. Tetrahedron Lett. 1999, 40, 3957-3960. doi:10.1016/S0040-4039(99)00620-6

21. Ruault, P.; Pilard, J.-F.; Touaux, B.; Texier-Boullet, F.; Hamelin, J. Synlett 1994, 935-936. doi:10.1055/s-1994-23054

22. Samajdar, S.; Becker, F. F.; Banik, B. K. Heterocycles 2001, 55, 1019-1022.

23. Banik, B. K.; Samajdar, S.; Banik, I. J. Org. Chem. 2004, 69, 213-216. doi:10.1021/jo035200

24. Yadav, J. S.; Reddy, B. V. S.; Satheesh, G. Tetrahedron Lett. 2004, 45, 3673-3676. doi:10.1016/j.tetlet.2004.03.039

25. Alizadeh, A.; Rezvanian, A.; Bijanzadeh, H. R. Synthesis 2008, 725-728. doi:10.1055/s-2008-1032168

26. Khalili, B.; Jajarmi, P.; Eftekhari-Sis, B.; Hashemi, M. M. J. Org. Chem. 2008, 73, 2090-2095. doi:10.1021/jo702385n And reference cited therein.

27. Saravanan, S.; Azath, I. A.; Muthusubramanian, S. J. Org. Chem. 2008, 73, 2323-2329. doi:10.1021/jo702610j

28. Pirrung, M. C.; Zhang, J.; Lackey, K.; Sternbach, D. D.; Brown, F. J. Org. Chem. 1995, 60, 2112-2124. doi:10.1021/jo00112a036

29. Cunha, A. C.; Pereira, L. O. R.; de Souza, R. O. P.; de Souza, M. C. B. V.; Ferreira, V. F. Synth. Commun. 2000, 40, 3215-3226. doi:10.1080/00397910008086932

30. Pereira, L. O. R.; Cunha, A. C.; de Souza, M. C. B. V.; Ferreira, V. F. J. Braz. Chem. Soc. 2002, 13, 368-374. doi:10.1590/S0103-50532002000300012

31. Kesteleyn, B.; Alonso, E. R.; Stevens, C.; Dejaegher, Y.; Peristeropoulou, M.; Van, T. N.; Kulinkovich, O.; De Kimpe, N. Tetrahedron 1999, 55, 4153-4166. doi:10.1016/S0040-4020(99)00108-8

32. Milić, B. L.; Piletić, M. V. Food Chem. 1984, 13, 165-180. doi:10.1016/0308-8146(84)90071-2
33. Ferreira, V. F. Ph.D. Thesis, Univ. California, 1984. Diss. Abstr. Int., B 1985, 45, 3232.

34. Khan, M. K. A.; Morgan, K. J.; Morrey, D. P. Tetrahedron 1966, 22 , 2095-2105. doi:10.1016/S0040-4020(01)82129-3

35. Rosenberger, M.; Yates, P.; Hendrickson, J. B.; Wolf, W. Tetrahedron Lett. 1964, 33, 2285-2289. doi:10.1016/S0040-4039(00)71704-7

36. Regitz, M.; Liedhegener, A. Chem. Ber. 1966, 99, 3128-3147. doi:10.1002/cber.19660991010

37. Arnold, Z.; Šauliová, J. Collect. Czech. Chem. Commun. 1973, 38, 2641-2647.

\section{License and Terms}

This is an Open Access article under the terms of the Creative Commons Attribution License

(http://creativecommons.org/licenses/by/2.0), which permits unrestricted use, distribution, and reproduction in any medium, provided the original work is properly cited.

The license is subject to the Beilstein Journal of Organic Chemistry terms and conditions:

(http://www.beilstein-journals.org/bjoc)

The definitive version of this article is the electronic one which can be found at: doi: $10.3762 /$ bjoc. 4.45 